\title{
VEGETABLE CONSUMER BEHAVIOR IN MARKET AREA OF JEMBER CITY
}

\author{
Kukuh Iswahyudi ${ }^{* 1}$, Henik Prayuginingsih"), Syamsul Hadi*), and Risa M. Muliasari*) \\ *) Department of Agribusiness, Faculty of Agriculture, University of Muhammadiyah Jember \\ Jl. Karimata No. 49, Building B 1st floor, Jember 68124
}

\begin{abstract}
Consumer behavior is needed as information material for traders in order to meet consumer needs. Vegetables have important for comsumers, therefore these commodities have great economic value for the agribusiness sector. The research aims to identify consumer behavior, determine the purchasing decision making process and analyze the factors that influence the buying behavior of vegetables in the Jember Regency area market. Data obtained from 100 respondents using a convenience sampling method and researched with attitude analysis $(\mathrm{Ab})$, subjective norm analysis $(\mathrm{SN})$, analysis of consumer behavior $(\mathrm{B} \sim \mathrm{BI})$ and factor analysis. The results of the analysis show that consumer behavior in buying vegetables in the Jember Regency City market area is as follows: (1) in traditional markets, is in neutral behavior, which is influenced by vegetable attributes; (2) In the modern market, it is likely behavior, which is influenced by the attributes of vegetables. Factors that influence consumers in making vegetable purchasing decisions in the Jember Regency region in a row are individual factors (age, education, income and lifestyle), psychological factors (beliefs, motivations and perceptions), social factors (family, close friends and coworkers), price factors (prices according to benefits and more affordable prices), distribution factors (product availability, seller services and location) and cultural factors (consumption habits).
\end{abstract}

Keywords: consumer behavior, factor analysis, market, purchasing decisions

\begin{abstract}
Abstrak: Perilaku konsumen diperlukan sebagai bahan informasi bagi pedagang agar dapatmemenuhi kebutuhan konsumen. Sayuranmemilikimanfaatyang penting bagi konsumen, oleh sebab itu komoditi ini memiliki nilai ekonomi yang besar bagi sector agribisnis. Tujuan penelitian adalah untuk mengidentifikasi perilaku konsumen, mengetahui proses pengambilan keputusan pembelian dan menganalisa faktor-faktor yang mempengaruhi perilaku keputusan pembelian sayuran di pasar wilayah Kota Kabupaten Jember. Data diperoleh dari 100 responden dengan metode convenience sampling serta diteliti dengan analisis sikap (Ab), analisis norma subyektif (SN), analisis perilaku konsumen (B BI) dan analisis faktor. Hasil analisis menunjukkan bahwa perilaku konsumen dalam membel isayuran di pasar wilayah Kota Kabupaten Jember adalah sebagai berikut: (1) pada pasar tradisional, berada pada perilaku netral, yang dipengaruhi oleh atribut sayuran; (2) Pada pasar modern, berada pada perilaku yang dipengaruhi oleh atribut sayuran. Faktor - faktor yang mempengaruhi konsumen dalam melakukan keputusan pembelian sayuran di pasar wilayah Kota Kabupaten Jember secara beruntun adalah factor individu (usia, Pendidikan, penghasilan dan gaya hidup), Faktor psikologis (keyakinan, motivasi dan persepsi), factor sosial (keluarga, teman dekat dan rekan kerja), factor harga (harga sesuai manfaat dan harga lebih terjangkau), factor distribusi (ketersediaan produk, pelayanan penjual dan lokasi) dan factor budaya (kebiasaan konsumsi).
\end{abstract}

Kata kunci: analisis faktor, keputusan pembelian, pasar, perilaku konsumen

\footnotetext{
${ }^{1}$ Corresponding author:

Email: kukuh.iswahyudi1996@gmail.com
} 


\section{INTRODUCTION}

Vegetables have important benefits for consumers, therefore this commodity has great economic value for the agribusiness sector. Karsin in Aswatini (2007) reveals that vegetables and fruits are one of the food groups in FAO processing known as the Hopeful Food Pattern (PPH). Consumption of vegetables is always related to vegetable production, vegetable products are generally sold in markets, where the market itself is divided into 2 types, namely traditional markets and modern markets. The presence of modern markets since the 90s has become an alternative for people to meet their needs. In addition to modern markets, there are also traditional markets which are very different from modern markets, if seen from the physical form of the building infrastructure is relatively older. Even so, not all traditional markets have such physical conditions, some of which are still neat, clean, and safe, but still with traditional management patterns (Center for State Research and Development in Fissamawati, 2009). There are some consumers who prefer traditional markets to buy vegetables, this is because traditional markets have advantages, namely social interaction between traders and buyers, the products being sold are still fresh and most markets provide various types of vegetables. There are also some consumers who prefer the modern market to buy fresh vegetables, this is because modern markets have advantages, namely neat vegetable storage racks, neat vegetable packaging and a clean place.

The increasingly fierce market competition conditions encourage producers and marketers to compete to provide products according to consumer needs and market the resulting products with a good marketing strategy. The goal is to keep producers getting the trust of consumers and the most important thing is to provide satisfaction to consumers, so that analysis of vegetable consumer behavior in traditional markets is needed. According to Simamora (2004) consumer behavior is a decision-making process that requires an individual activity to take, use or manage goods and services. Based on the background that has been described, it is interesting to conduct an analysis of the behavior of vegetable consumers in the markets of the City of Jember Regency with the aim of: (1) To identify consumer behavior in buying vegetables in the regional markets of the City of Jember Regency, (2) To see the decision making process in buying vegetables in the regional markets of the City of Jember Regency and
(3) To analyze the factors that influence the behavior of vegetable purchasing decisions in the regional markets of the City of Jember Regency.

\section{METHODS}

This research was conducted in the urban area of Jember, which consists of traditional and modern markets. Traditional markets are located at Tanjung market, while modern markets are located at Lippo Hypermarket and TransmartJember. This location was chosen purposively with the consideration that Tanjung market is the largest traditional market in Jember while Lippo Hypermarket and TransmartJember is a modern market located in the city of Jember that sells vegetables. The research was conducted in September - October 2019.

The method used in this research is descriptive analytic. Nazir (1999) states that descriptive analytic is a method of researching a group of people, an object, a set of conditions, a system of thought or a class of events in the present by collecting data, compiling, analyzing, and dancing according to Wirartha (2006). The analytical descriptive method is concerned with collecting data to provide an overview or affirmation of a concept or symptom, as well as answering questions regarding the current status of research objects, for example attitudes or opinions towards individuals, organizations and so on. conclusions and interpret them.

The sampling method was convenience sampling, which is a group of non-probability sampling. This method considers the convenience, availability and convenience of sampling. The requirements for consumers who can become respondents are consumers who purchase vegetables for household needs in the markets in the City of Jember. The researcher determined 100 respondents using the Slovin formula. Because the research site is located in the city area and is divided into 2 types of markets, then the number of respondents is divided using quota sampling so that 50 respondents are in traditional markets and 50 respondents in modern markets.

Method of collecting data. based on the type of data used in the study:

1) Qualitative data, namely data based on facts of opinion and rational thinking related to consumer behavior problems towards the attributes of 
vegetables in the market in the city of Jember.

2) Quantitative data, namely the data used in the form of numbers which are used to test hypotheses about consumer behavior and the factors for making decisions about purchasing vegetables in the market in the city of Jember.

Based on the data sources used in the study are as follows:

1) Primary data is data obtained directly from the source, observed and recorded for the first time by the researcher. Primary data in this study are the results of answers to questionnaires made by researchers from respondents.

2) Secondary data is data obtained indirectly from sources in the form of journals, Central Bureau of Statistics and others, which are related to this research. To find out responsive opinions in answering the questions that will be asked. Then a questionnaire was used as a data collection tool, a number of written questions that were useful for obtaining respondent information.

Data analysis method

\section{Attitude Analysis (Ab)}

According to Umar in Adilah's (2017) study to determine the effect of consumer attitudes $(\mathrm{Ab})$ on the attributes of vegetables in traditional and modern markets in determining consumer buying behavior, the Fishbein model analysis was used as follows:

$$
\begin{gathered}
A b=\sum_{i=1}^{n} b_{i} e_{i} \\
b_{i}=\frac{\sum_{i=1}^{n} r_{i} f\left(X_{i}\right)}{n} \quad \text { ei }=\frac{\sum_{i=1}^{n} r_{i} f\left(y_{i}\right)}{n}
\end{gathered}
$$

Information: $\mathrm{Ab}$ (Total individual attitudes towards vegetable attributes in the Municipal Market); Bi

(Strength of consumer confidence in the attributes of vegetables in the Municipal Market (Score: 1, 2,3, 4 and 5)); Ei (Evaluation of the vegetable attributes in the Municipal Market (Score: 1, 2, 3, 4 and 5)); Ri (The weight of the score - i); f (xi) (The number of respondents who have a weighted score to $=i$ for the confidence variable (bi)); f (yi) (Number of respondents who have a weighted score to $=\mathrm{i}$ for the evaluation variable (ei)).

\section{Subjective Norms Analysis (SN)}

According to Umar in Adilah (2017) to find out the effect of subjective norms ( $\mathrm{SN}$ ) arising from referrals (friends and family) has an impact on consumer purchasing behavior towards fresh vegetables in traditional and modern markets using the following formula:

$$
\begin{gathered}
S N=\sum_{j=1}^{n} N B_{j} M C_{j} \\
N B_{j}=\frac{\sum_{j=1}^{n} r_{j} f\left(x_{j}\right)}{n} \quad M C_{j}=\frac{\sum_{j=1}^{n} r_{j} f\left(y_{j}\right)}{n}
\end{gathered}
$$

Information: SN (Subjective Norms); NBj (Individual normative beliefs (Score: 1, 2, 3, 4, 5)); $\mathrm{MCj}$ (Motivation from referrals (Score: 1, 2, 3, 4, 5)); rj (Weighted score - $\mathrm{j}$ ); $\mathrm{f}(\mathrm{xj})$ (The number of respondents who have weighted the jth score for the normative belief variable (NBj)); $\mathrm{f}(\mathrm{yj})$ (The number of respondents who have weighted the Jth score for the Motivation variable (MCj)).

\section{Consumer Behavior Analysis}

Based on consumer attitudes and consumer subjective norms, the following equation is used (Umar in Danang Sunyonto, 2014):

$$
\begin{gathered}
\mathrm{B} \sim \mathrm{BI}=\mathrm{W}_{1}(\mathrm{Ab})+\mathrm{W}_{2}(\mathrm{SN}) \\
\mathrm{Ab}=\sum_{i=1}^{n} b_{i} e_{i} \quad \mathrm{SN}=\sum_{j=1}^{n} N B_{j} M C_{j} \\
\mathrm{~W} 1=\frac{G M A b}{G M A b+G M S N} \quad \mathrm{~W} 2=\frac{G M S N}{G M A b+G M S N}
\end{gathered}
$$

Information: B (Consumer behavior); BI (Behavior Intent); $\mathrm{Ab}$ (Total attitude towards attributes vegetables); SN (Subjective Norms Vegetable Attribute); GMAb (The calculation result of $\sum \mathrm{bi}+\sum$ ei divided by the number of attributes) GMSN (Calculation result of $\sum \mathrm{NBj}+\sum \mathrm{MCj}$ divided by the number of referents); W1,W2 (Weights found empirically, describing the relative effects of components). If more decisions are made by consumers themselves, then the value of W1> W2. Conversely, if more decisions are made due to the influence of other parties, then $\mathrm{W} 1<\mathrm{W} 2$. 


\section{Decision Making Analysis}

To analyze the purchase decision making using descriptive analysis, namely data which isa decisionmaking process grouped based on the same answer, then percentage based on the number of respondents. The largest percentage is the dominant factor of each of the variables studied.

\section{Factor Analysis}

Factor analysis is a model, in which there are no independent and dependent variables. Factor analysis does not classify variables into the independent and dependent variable category but looks for interdependent relationships between variables in order to identify the dimensions or factors that make up them. Factor analysis was first performed by Charles Spearman, with the main objective of factor analysis is to explain the relationship between many variables in the form of several factors, these factors are random quantities that can be observed or measured directly. The main use of factor analysis is to reduce data or in other words summarize a number of variables that will be small in number. Reduction is done by looking at the interdependence of several variables that can be made into one which is called a factor. So that it is found variables or factors that are dominant or important for further analysis (Jonathan Sarwono, 2006). The factor analysis equation or formula is as follows:

$$
\mathrm{Fi}=\mathrm{Wi}_{1} \mathrm{X}_{1}+\mathrm{Wi}_{2} \mathrm{X}_{2}+\ldots \mathrm{Wi}_{\mathrm{k}} \mathrm{X}_{\mathrm{k}}
$$

Where: $\mathrm{F}_{\mathrm{i}}$ (Factor to I estimate), $\mathrm{W}_{\mathrm{i}}$ (Factor weight or factor coefficient score, $\mathrm{X}_{\mathrm{k}}$ (Purchase decision variable observed, The purchasing decision variables observed are: $\mathrm{X}_{1}$ (Product Factor), $\mathrm{X}_{2}$ (Price factor), $\mathrm{X}_{3}$ (Distribution Factors, $\mathrm{X}_{4}$ (Cultural Factors), $\mathrm{X}_{5}$ (Individual Factors), $\mathrm{X}_{6}$ (Social Factors), and $\mathrm{X}_{7}$ (Psychological Factors)).

\section{RESULTS}

\section{Consumer Behavior}

The consumer behavior model used in this research is behavior analysis using TRA (The Theory of ReasonedAction) which is part of Fishbein's multi-attribute attitude model. The TRA model explains that behavior is influenced by behavioral interest. Interest in behavior consists of a component of attitude (Ab) and subjective norm $(\mathrm{SN})$. Furthermore, attitude $(\mathrm{Ab})$ is obtained from two variables, namely the beliefs held by consumers (bi) and evaluation of the consequences of beliefs (ei) with attributes. Subjective norms are also obtained from two variables, namely consumer normative beliefs towards referents (NBj) and consumer motivation to comply with referent influences $(\mathrm{MCj})$, as well as empirical weight calculations W1 for attitudes and W2 for subjective norms which are the relative influence of components. The following is the results of the calculation of the behavior of vegetable consumers in the Jember district city area which is presented in Table 1.

Based on Table 1, it shows that in traditional markets partially the average values of bi and ei are 3.91 and 3.67 , both of which are at positive score intervals and in modern markets partially the average values of bi and ei are 4.16 and 3.92 respectively, both of which are at positive score intervals, then after the bi and ei scores are multiplied in traditional and modern markets, it will produce a total attitude in traditional markets of 73.54 which is in the neutral score interval and total attitude in modern markets of 81.88 which is in the positive score interval. Likewise with the calculation of subjective norms, in traditional markets the value of $\mathrm{NBj}$ is 3.63 which is in the positive score interval and $\mathrm{MCj}$ is 3.35 which is in the neutral score interval while in modern markets partially the average $\mathrm{NBj}$ and $\mathrm{MCj}$ values are 4, 06 and 3.90 which are in the positive score interval, after the $\mathrm{NBj}$ and $\mathrm{MCj}$ values are multiplied, then in traditional markets it produces a subjective norm of 25.76 which is in the neutral score interval while in modern markets it produces a subjective norm of 32.48 which is at score intervals are advocated. In traditional markets the values of $\mathrm{W} 1$ and $\mathrm{W} 2$ are 0.52 and 0.48 and in modern markets the values of $\mathrm{W} 1$ and $\mathrm{W} 2$ are 0.51 and 0.49 , the values of $\mathrm{W} 1$ and $\mathrm{W} 2$ in both types of markets are obtained from the empirical weight calculations of GMAb and GMSN for both types. In this market, the two types of markets show the same results, namely consumer purchases are more dominated by oneself than others, this explanation can be seen from the value of $\mathrm{W} 1$ which is greater than W2. Furthermore, the value of consumer behavior from the two types of markets is very different, where in traditional markets with a value of 3 which is at a neutral score interval while in modern markets with a value of 4 which is in the possible score interval yes, the value of consumer behavior in the two types of markets obtained from the attitude score multiplied by 
the attitude weight (W1) then added by the subjective norm score multiplied by the subjective norm weight (W2).

\section{Decision Making Process}

The characteristics and diverse backgrounds of consumers will influence purchasing decisions to buy products. The process of making consumer decisions in buying vegetables at the market in the city of Jember Regency begins when consumers feel and recognize the need for a product. Awareness of the needs that must be met makes consumers look for products that can solve the perceived problem. In detail, consumers who buy fresh vegetables at the market in the city of Jember Regency determine their purchasing decisions through several stages, namely the stages of identifying needs, seeking information, evaluating alternatives, purchasing decisions, and post-purchase behavior. The decision-making process of consumers in buying vegetables in markets in the Jember district city area is divided based on the introduction of traditional markets and modern markets, starting when consumers feel and recognize the need for fresh vegetable products. The stage of identifying needs can be started from detecting the motivation or reasons for consumers to purchase fresh vegetables at markets in the city of Jember Regency. The motivation of each consumer to consume a product is different. The motivation of respondents in buying vegetables in the market in the city of Jember Regency is because it is safe for health as indicated by the percentage value of 60 percent in traditional markets and 100 percent in modern markets in buying vegetables, this is due to the diverse backgrounds of consumers, so that gender differences, age, occupation, education and income of consumers can influence consumer motivation in buying vegetables in markets in the city of Jember Regency. Meanwhile, 36 percent answered the motivation to buy fresh vegetables based on the manifestation of a healthy lifestyle, and 4 percent of the traditional market respondents answered that their motivation to buy fresh vegetables was just trial and error.

After the consumer's motivation to buy and consume fresh vegetables is known, then the motivation based on the benefits expected by consumers after consuming vegetables in the market in the city of Jember Regency is the fulfillment of nutrition with a value of 48 percent in traditional markets and 100 percent in modern markets. Meanwhile, most consumers in traditional markets answered that it was the fulfillment of a healthy lifestyle. And 2 percent answered as herbal medicinal ingredients.

The next stage is finding information about the whereabouts of fresh vegetables that consumers want to buy. Information searches can be carried out by consumers in two ways, namely searching (knowledge stored in memory) and external searching (information from the environment). Information on buying fresh vegetables at markets in the urban area of KabupatenJember is mostly influenced by families, with a percentage value of 88 percent for traditional markets and 64 percent for modern markets.

Table 1. Results of calculation of vegetable consumer behavior in the regional market of the City of Jember Regency

\begin{tabular}{|c|c|c|c|c|}
\hline \multirow{2}{*}{ Component } & \multicolumn{2}{|c|}{ Traditional Market } & \multicolumn{2}{|c|}{ Modern Market } \\
\hline & value & Score Interval & Value & Score Interval \\
\hline Consumer Behavior & 3 & Netral & 4 & Possibility Yes \\
\hline Attitude (Ab) & 73.54 & Netral & 81.88 & Positif \\
\hline Beliefs (bi) & 3.91 & Positif & 4.16 & Positif \\
\hline Evaluation (ei) & 3.67 & Positif & 3.92 & Positif \\
\hline Subjective Norms (SN) & 25.76 & Netral & 32.48 & Recommend \\
\hline Normative Beliefs (NBj) & 3.63 & Positif & 4.06 & Positif \\
\hline Motivation Follows (MCj) & 3.35 & Netral & 3.90 & Positif \\
\hline \multicolumn{5}{|l|}{ Empirical weight } \\
\hline Empirical Weight of Attitude (W1) & 0.52 & & 0.51 & \\
\hline Empirical Weight of Sujective NormsSubyektif (W2) & 0.48 & & 0.49 & \\
\hline
\end{tabular}


After the search for information is known, then the focus of purchases based on the information received is on benefits, with a value of 46 percent in traditional markets, the rest who answered based on price with a value of 38 percent and 16 percent answered based on nutritional content. Meanwhile, the modern market answered based on benefits with a value of 66 percent, 16 percent nutritional content, 12 percent lifestyle, and 6 percent price. The next stage is an alternative evaluation of what consumers consider in determining where to buy vegetables. The benefits of vegetables are considered in the evaluation of purchasing vegetables in the municipal markets of Jember Regency, with a value of 46 percent in traditional markets and 66 percent in modern markets. The next stage is a purchasing decision, which is related to how to decide to buy vegetables in the market in the city of Jember district. 50 respondents or 100 percent said that the decision to buy fresh vegetables in traditional markets was planned, while in modern markets 80 percent of respondents said it was planned, 14 percent said it was sudden and 6 percent said it depends on the situation. After the decision to make a purchase has been determined, then the next is the frequency of consumer purchases in a month, where in traditional markets the highest frequency value is 52 percent with a purchase frequency of more than 3 times a month, while in modern markets the highest frequency value is 88 percent with the frequency of purchases once a month. The last stage of the purchase decision process, this stage is how customer satisfaction is about a product that has been purchased and whether to make repeat purchases for that product. At this stage of postpurchase behavior, consumers give their opinion about their satisfaction after shopping in the Jember district city market, in traditional markets all consumers are very satisfied after buying vegetables, namely 50 consumers or $100 \%$, while in modern markets most consumers say they are very satisfied. satisfied with the value of $80 \%$ and the rest said they were satisfied with the value of $10 \%$ and $10 \%$ normal. This consumer satisfaction is due to the total satisfaction of the stages that have been studied by consumers.

\section{Factor Analysis}

Vegetable purchasing decisions made by consumers in the Jember district municipal market were analyzed using the spss factor analysis method. Factor analysis can identify the factors that influence consumer purchasing decisions in buying vegetables in the Jember district market, where these factors are product, price, distribution, culture, individual, social and psychological. Furthermore, these factors will be analyzed using SPSS factor analysis to find out what factors influence the decision to buy vegetables in the market in the municipal area of Jember Regency. The results of the factor analysis will show how much the contribution of the factors summarized in influencing consumer purchasing decisions in the market area of the city of Jember Regency. The first test of factor analysis of vegetable purchasing decisions uses the Keizer Mayor Olkin (KMO) and Barlett's Test to see whether the factors studied have a Measure Of Sampling Adequency (MSA) value greater than 0.5 . Next, look at the Anti - image Correlation value of each variable $>$ 0.5 . If the Anti-image Correlation result is $<0.5$, then the variable is removed from the model and performs back analysis until the Anti-image Correlation value is formed above 0.5 . In the further analysis of the variable factors that influence the vegetable purchasing decision, there is 1 factor that is outlined, namely Product (X1). After elimination, the results are shown in Tables 2 and 3.

Based on Table 2, after removing the product factor, the latest value from the analysis of KMO and Barlett's Test values is 0.534 with a significance of 0.549 , then the existing variables can still be analyzed further, then they are the results of retesting the MSA (Measure of Sampling Adequacy). From the results of this analysisit can be interpreted that the factors formed can be further analyzed. Table 2 is the result of the analysis of price, distribution, culture, individual, social and psychological factors.

The next step from the factor analysis stage is to determine the MSA value of the Anti-image Correlation of each factor which must be above 0.5. Table 3 shows the results of the MSA value from the Anti-image Correlation of 6 factors that have an MSA value> 0.5 so that further analysis can be carried out by carrying out the Extraction and Rotation processes to see the relationship between factors.

The next stage that needs to be assessed is the Communalities table. Communalities is an analysis which is basically the number of factors (can be as a percentage) of an initial factor that can be explained by the forming factors. The amount of communalities for each different factor can be seen in Table 4 . 
Table 2. Test Value of Keiser - Meyer Olkin

\begin{tabular}{lc}
\hline Informations & Value \\
\hline KMO - MSA & 0.534 \\
Barlett's Test of Sphericity & 13.698 \\
Df & 15 \\
Sig. & 0.549 \\
\hline
\end{tabular}

Table 3. Value of MSA Anti - Image Correlation

\begin{tabular}{ll}
\hline Factor & MSA \\
\hline Price & 0.593 \\
Distribution & 0.506 \\
Culture & 0.542 \\
Individual & 0.515 \\
Social & 0.517 \\
Psychological & 0.545 \\
\hline
\end{tabular}

Table 4. Communalities

\begin{tabular}{lc}
\hline Variable & Extracion \\
\hline Proce & 0.324 \\
Distribution & 0.792 \\
Culture & 0.457 \\
Individual & 0.667 \\
Social & 0.712 \\
Psychological & 0.534 \\
\hline
\end{tabular}

Table 4 is the value is the varins value of each factor. If sorted from largest to smallest varinas value, the order is:

1) Distribution (0.792); The distribution factor has a communalities value of $79.2 \%$, which means that the variance of the distribution factor can be explained by the variables of product availability, sales service and location.

2) Social (0.712); social factors have a communalities value of $71.2 \%$ which means that social variance can be explained by family, close friends and coworkers variables.

3) Individual (0.667); The individual factor has a communalities value of $66.7 \%$ which means that social variance can be explained by the variables of age, education, income and lifestyle.

4) Psychological (0.534); Psychological factors have a communalities value of $53.4 \%$ which means that psychological variance can be explained by the variables of belief, motivation and perception.

5) Culture (0.457); Cultural factors have a communalities value of $45.7 \%$ which means that cultural variance can be explained by the variable consumption habits.
6) Price (0.324); the price factor has a communalities value of $32.4 \%$ which means that the price variance can be explained by price variables according to benefits and affordable prices.

The next interpretation of the factor analysis is Total Variance Explained, where the criteria for a factor that influences the decision to buy vegetables in the market in the Jember regency can be seen by looking at the eigenvalue of a factor. Factors that influence vegetable purchasing decisions must have an eigenvalue greater than or equal to one.

Table 5 shows that there are 3 components that have an eigenvalue value above one $(>1)$, this explains that from the 6 factors analyzed by the factoring process, 3 components are formed that influence consumers in making vegetable purchasing decisions in the market in the Jember district. This shows the grouping of a number of factors into certain components, because there are similarities in the characteristics of certain factors. Component 1 explains the variance proportion value of $23.846 \%$ of the 6 research factors analyzed, Component 2 explains the variance proportion value of $17.380 \%$ of the 6 research factors analyzed and Component 3 explains the variance proportion value of $16.879 \%$ of the 6 research factors. If the eigenvalue value shows a number, the scree plot shows it with a graph.

Figure 1 shows that the eigenvalue value from component 1 to component 2 is depicted with a sharp decreasing line, then the eigenvalue value has decreased from component 2 to component 6.Thevalue of components 1 to 3 is greater than 1 , while the decrease that occurs after component 3 shows that the eigenvalue value is less than 1, thus components 1 to 3 are 3 factors that are appropriate to summarize the 6 research factors.

After producing 3 appropriate factors to summarize the 6 research factors, then we obtain the matrixa component factor table that influences the purchase decision, which consists of the initial factors on the formed factors, by looking at the size of the loadings factor, which factor can be determined which factors enter. The greater the loadings value of a factor, the stronger the correlation between the factors and the forming factors. The factor loading value is determined from a value $>0.5$. If in correlation there are two or more loading factors whose value is greater than 0.5 , a Rotation press is performed which will produce a Rotated component matrix. 
Figure 1 shows that the eigenvalue value from component 1 to component 2 is depicted with a sharp decreasing line, then the eigenvalue value has decreased from component 2 to component 6.The value of components 1 to 3 is greater than 1 , while the decrease that occurs after component 3 shows that the eigenvalue value is less than 1 , thus components 1 to 3 are 3 factors that are appropriate to summarize the 6 research factors.

After producing 3 appropriate factors to summarize the 6 research factors, then we obtain the matrixa component factor table that influences the purchase decision, which consists of the initial factors on the formed factors, by looking at the size of the loadings factor, which factor can be determined which factors enter. The greater the loadings value of a factor, the stronger the correlation between the factors and the forming factors. The factor loading value is determined from a value $>0.5$. If in correlation there are two or more loading factors whose value is greater than 0.5 , a Rotation press is performed which will produce a Rotated component matrix.

From the Table 6 , it can be seen that the rotation used is varimax by correlating the dominant variable with one factor. From this table it can be interpreted that:

a. The individual factor with a higher correlation value, namely 0.725 , is contained in component 1 .

b. Psychological factors with a higher correlation value, namely 0.664 contained in component 1 .

c. The social factor with a higher correlation value is 0.833 which is in component 2 .

d. The price factor with a higher correlation value, namely 0.517 contained in component 2 .

e. The distribution factor with a higher correlation value, namely 0.886 contained in component 3 .

f. Cultural factors with a higher correlation value, namely 0.501 contained in component 3 .

After the rotation of the matrix components is known, then the transformation of the matrix components will be carried out which can be seen in Table 7. From the table, it can be explained that the diagonal numbers from top left to bottom right have the highest correlation value in each component, this shows that the three components formed are correct. The correlation value is 0.644 in component $1,0.833$ in component 2 and 0.706 in component 3 . From the results of the factor analysis that has been carried out, it can be concluded that the second hypothesis is rejected, because of the 7 factors analyzed, there are only 6 factors that influence consumers in purchasing decisions for vegetables in the markets of the City of Jember Regency, which include:

1. Individual factors (age, education, income and lifestyle);

2. Psychological factors (beliefs, motivation and perceptions);

3. Social factors (family, close friends and colleagues);

4. Price factor (price according to benefits and more affordable price);

5. Distribution factors (product availability, seller services and location);

6. Cultural factors (consumption habits).

Table 5. Eigenvalue of Total Variance

\begin{tabular}{lcc}
\hline Component & Eigenvalue & Proportion Variance \\
\hline 1 & 1,431 & $23,846 \%$ \\
2 & 1,043 & $17,380 \%$ \\
3 & 1,013 & $16,879 \%$ \\
Total & 4,260 & $58,105 \%$ \\
\hline
\end{tabular}

Table 6. Rotated Component Matrix

\begin{tabular}{lccc}
\hline \multirow{2}{*}{ Factor } & \multicolumn{3}{c}{ Component } \\
\cline { 2 - 4 } & 1 & 2 & 3 \\
\hline Individual & 0,725 & 0,314 & $-0,205$ \\
Psychological & 0,664 & $-0,229$ & 0,201 \\
Social & $-0,132$ & 0,833 & $-0,001$ \\
Price & 0,181 & 0,517 & 0,156 \\
Distribution & $-0,076$ & 0,047 & 0,886 \\
Culture & 0,408 & 0,199 & 0,501 \\
\hline
\end{tabular}

Table 7. Matrix Component Transformation

\begin{tabular}{cccc}
\hline Component & 1 & 2 & 3 \\
\hline 1 & 0,644 & 0,539 & 0,542 \\
2 & $-0,315$ & 0,833 & $-0,455$ \\
3 & $-0,697$ & 0,122 & 0,706 \\
\hline
\end{tabular}

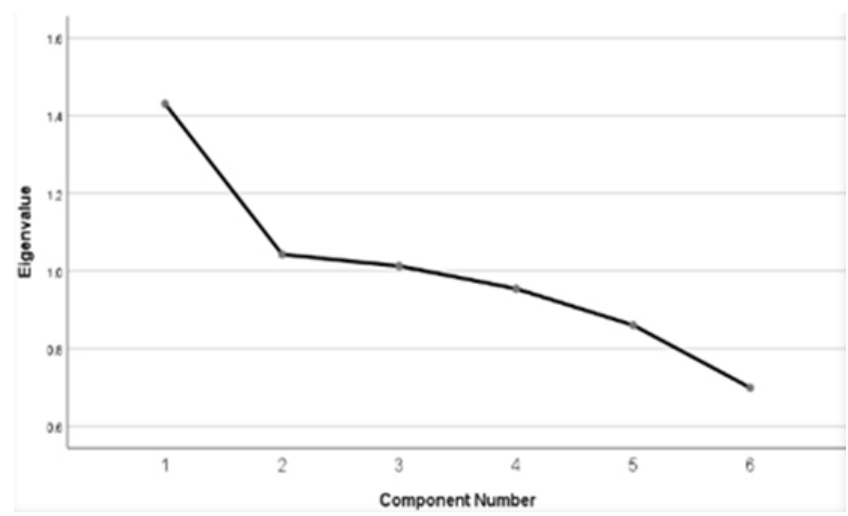

Figure 1. Graph Scree Plot 


\section{Managerial Implications}

It is important for vegetable producers in both traditional and modern markets to pay attention to individual, psychological, social, price, distribution and cultural factors, because these six factors influence the purchasing decisions of vegetable consumers in Jember City.

\section{CONCLUSIONS AND RECOMMENDATIONS}

\section{Conclusions}

Consumer behavior in buying vegetables in the markets in the City of Jember Regency is as follows: a) In traditional markets, are in neutral behavior. Those influenced by vegetable attributes in order from highest to lowest score are as follows: freshness of vegetables, brightness of color, cleanliness of vegetables, availability of vegetables and price of vegetables; $b$ ) In the modern market, be in the behavior of a possibility yes. Those influenced by vegetable attributes in order from highest to lowest score are as follows: cleanliness of vegetables, freshness of vegetables, brightness of color, price of vegetables and availability of vegetables.

The decisionmaking process for purchasing vegetables in the regional market of the City of Jember Regency is as follows: a) In traditional markets, starting with the need recognition stage, namely the motivation to buy vegetables, consumers think that vegetables are safe for health with the hope that they will manifest a healthy lifestyle. Information on the sale of vegetables is obtained by consumers from their families, with the focus on purchasing vegetables on the benefits of vegetables. At the alternative evaluation stage, consumers consider the benefits of vegetables more; b) In the modern market, starting with the need recognition stage, namely the motivation to buy vegetables, consumers think that vegetables are safe for health with the hope that they are guaranteed nutritional fulfillment. The information on the sale of vegetables is obtained by consumers from the family, with the focus of purchasing it on benefits. At the alternative evaluation stage, consumers consider the benefits of vegetables more.

Factors that influence consumers in making vegetable purchasing decisions in the regional markets of Jember Regency are individual factors (age, education, income and lifestyle), psychological factors (belief, motivation and perception), social factors (family, close friends and co-workers), price factors (prices according to benefits and more affordable prices), distribution factors (product availability, seller services and location) and cultural factors (consumption habits).

\section{Recommendations}

To increase role of the factors that influence purchasing decisions of vegetable consumers in Jember City, it is recommended that producers create promotion that involves lifestyle, experts to convince and the community. In addition, the price is recommended to be more affordable and always available and strategic sales locations. For related government agencies such as the Trade and Industry Office and the Market Service, it is hoped that this can be used as information to participate in making advertisements that invite people to eat vegetables. Can be a reference for similar research, for future researchers, by changing the object of research, namely various types of fish, fruits or various types of meat.

\section{REFERENCES}

Adilah S. 2018. Analisis perilaku konsumen terhadap sayuran segar di Hypermart Lombok Epicentrum Mall Kota Mataram [Skripsi]. Mataram: FakultasPertanian, Universitas Mataram.

Ajzen I, Fishbein. 1980. Theory of Reasoned Action. Edisi Kesatu. Oleh Jogiyanto. Yogyakarta: Andi Publisher.

Aswatini MN, Fitrianita. 2008. Konsumsi sayur dan buah di masyarakat dalam konteks pemenuhan gizi seimbang. Jurnal Kependudukan Indonesia III(2).

Fissamawati F. 2009. Analisis keputusan pembelian konsumen sayuran di pasar tradisional (studi Kasus Pasar Baru Bogor) [Skripsi]. Bogor: Institusi Pertanian Bogor.

Simamora B. 2002. Panduan Riset Perilaku Konsumen. Jakarta: Gramedia Pustaka.

Tunjungsari FD. 2009. Analisis perilaku konsumen terhadap pembelian ikan kakakp merah di pasar tradisional Kota Surakarta [Skripsi]. Surakarta: Fakultas Pertanian, Universitas Sebelas Maret. 